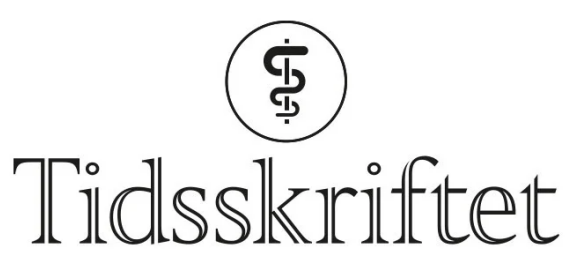

DEN NORSKE LEGEFORENING

\title{
Risikofaktorer for hepatitt C-smitte blant sprøytemisbrukere
}

ORIGINALARTIKKEL

\section{OLAV DALGARD}

Email: odalgard@medisin.uio.no

Rikshospitalet

o027 Oslo

Medisinsk avdeling

\section{ATLE EGELAND}

Rusmiddeletaten

Oslo kommune

\section{RANDI ERVIK}

Statens institutt for rusmiddelforskning Oslo

KOSTAS VILIMAS

Helse- og velferdsetaten

Oslo kommune

\section{KJELL SKAUG}

Folkehelseinstituttet

Oslo

\section{TORE W. STEEN}

Helse- og velferdsetaten

Oslo kommune

\section{BAKGRUNN.}

Hepatitt C-virusinfeksjon er vanlig blant injiserende stoffmisbrukere. Målet med denne studien var å undersøke forekomst av risikoatferd blant injiserende stoffmisbrukere i Oslo og deres assosiasjon med hepatitt C-smitte. 
Dette er en tverrsnittsundersøkelse, der 327 brukere av sprøytebussen i Oslo valgte å delta. Det ble foretatt et strukturert intervju som fokuserte på type rusmisbruk og risikoatferd med tanke på smitte. Blodprøver ble undersøkt for anti-hepatitt C-virus (anti-HCV) (EIA-3) og HCV-RNA (internt utført PCR).

\section{RESULTATER.}

Prevalensen av HCV-RNA var $51 \%$, og $81 \%$ var anti-HCV-positive (anti-HCV+). I en multivariatanalyse var anti-HCV+ assosiert med debutalder for sprøytemisbruk < 20 år, mer enn fem års sprøytemisbruk, alder ved inklusjon > 34 år, deling av sprøyter, sprøytemisbruk i fengsel, deling av dose fra felles sprøyte og heroinbruk. En av fem med anti-HCV+ oppga aldri å ha delt sprøyter, men anti-HCV+ var ikke assosiert med deling av annet brukerutstyr enn sprøyter. Målt i de siste fire ukene før intervjuet var deling av sprøyter vanligere blant gifte/samboende enn aleneboende.

\section{FORTOLKNING.}

De fleste sprøytemisbrukere i Oslo er blitt eksponert for hepatitt C (anti HCV+), og halvparten har utviklet kronisk infeksjon (HCV-RNA+). Hepatitt C-smitte var blant annet assosiert med deling av dose fra felles sprøyte og deling av sprøyter, særlig i fengsel. Deling av annet utstyr enn sprøyter var ikke assosiert med smitte.

\section{Tabell}

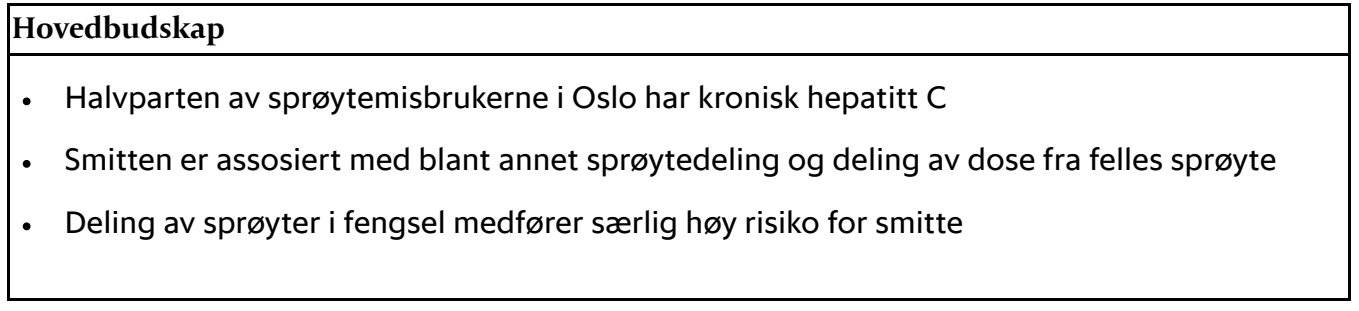

Infeksjon med hepatitt C-viruset (HCV) er et globalt folkehelseproblem og omkring 170 millioner mennesker er anti-hepatitt C-positive (anti-HCV+) (1). I den vestlige verden er sykdommen først og fremst en epidemi blant rusavhengige, og urene sprøyter er viktigste smittevei. Serologiske unders $\emptyset$ kelser har vist at $40-95 \%$ av injiserende stoffmisbrukere har vært eksponert for hepatitt C $(\underline{2}, 3)$. Blant nordmenn med kronisk hepatitt C oppgir 80 \% at de har injisert stoff ved minst én anledning (4). Kronisk infeksjon utvikler seg hos 6o-85\% av de eksponerte, og disse står i fare for å utvikle cirrhose og hepatocellulært karsinom (5). Hvor stor andel som vil nå sykdommens endestadium, er fortsatt uavklart. Studier av forløpet de første 20-30 årene etter eksponering tyder på at $20 \%$ vil utvikle cirrhose, men mange er blitt eksponert sent i ungdomstiden eller i 20-årsalderen, og lite er kjent om risikoen for å utvikle cirrhose etter fylte 50 år. Kronisk hepatitt $\mathrm{C}$ har antakelig vært endemisk blant norske sprøytemisbrukere siden tidlig i 1970-årene. I blodprøver samlet $\mathrm{i}$ 1979 blant norske misbrukere kunne anti-HCV påvises hos $56 \%$ (므). I et screeningprogram gjennomført blant brukere av sprøytebussen i Oslo i 2000 og 2001 var prevalensen av antiHCV 70 \%, mens hivinfeksjon ble påvist hos 1-2 \% (7.).

Med håp om å forebygge smitte blant misbrukere har gratis, rene sprøyter blitt gjort lett tilgjengelig gjennom offentlige program i Oslo siden 1988. Allikevel ser det ut til at spredningen av hepatitt C-virus fortsetter med uforminsket kraft. Dette tilsynelatende paradokset tilsier at det er behov for mer kunnskap om smitteoverføring av hepatitt C blant misbrukere. 
Målet med denne studien var å påvise assosiasjoner mellom injiseringsatferd og hepatitt Csmitte.

\section{Materiale og metode}

Studiepopulasjonen ble rekruttert blant brukere av sprøytebussen i Oslo. Dette programmet er antatt å betjene $90 \%$ av om lag 5000 aktive sprøytemisbrukere i Oslo. Programmet tilbyr brukerne gratis sterile sprøyter og kanyler 365 dager i året. Rusavhengige under 18 år kan ikke bruke programmet.

Denne tverrsnittsundersøkelsen ble gjennomført i en 11 dagers periode høsten 2002. Alle brukere av sprøytebussen i Oslo i perioden som noen gang hadde injisert et rusmiddel, ble forespurt om å delta. Studien foregikk samtidig med en veletablert årlig smittevernskampanje som tilbyr hepatitt A- og hepatitt B-vaksine, tuberkulosescreening ved skjermbildekontroll og serologiske undersøkelser blant annet med tanke på hepatitt C-infeksjon. En brosjyre om kampanjen ble delt ut til brukerne av sprøytebussen to uker før den ble gjennomført, og de ble spurt om å delta umiddelbart før undersøkelsen.

I studieperioden ble 3697 bes $\emptyset \mathrm{k}$ registrert. Mange bes $\varnothing \mathrm{kte}$ programmet flere ganger under perioden, men brukernes identitet kunne i henhold til retningslinjene for drift av programmet ikke registreres. Nøyaktig antall brukere i perioden er derfor ikke kjent.

Respondentene tok en blodprøve på stedet, og et systematisk intervju ble umiddelbart etterpå foretatt av trent personale. I intervjuet vektla man stoffbruk, atferd i forbindelse med injisering og erfaring med fengsling. Tidspunkt for første injeksjon, hyppighet av injeksjoner og foretrukne narkotiske stoff ble registrert. Spørsmål om atferd i forbindelse med injisering omhandlet deling av sprøyter og annet injiseringsutstyr, slik som kokeskje, (bomulls-)dotter og skyllevann. Spørsmål om fengselserfaring omhandlet varighet av soning og om hvorvidt respondenten injiserte i denne perioden.

Det ble ikke gjennomført systematisk registrering av årsaker til at inviterte ikke deltok. Lett til moderat ruspåvirkning utelukket ikke brukere fra å delta, men tungt påvirkede personer ble ikke invitert.

\section{LABORATORIEANALYSER}

Sera ble fryst innen fire timer etter prøvetaking og lagret ved $-70^{\circ} \mathrm{C}$ for senere analysering. Prøvene ble kun tint én gang og ble da undersøkt for hepatitt C-antistoffer (anti-HCV) med en EIA-3-analyse (Ortho Clinical Diagnostics, Raritan, New Jersey) og for HCV-RNA med en internt utført polymerasekjedereaksjons (PCR)-amplifikasjon av viralt RNA (nedre deteksjongrense om lag $100 \mathrm{IU} / \mathrm{ml}$ ). Prøvene ble også undersøkt med tanke på hepatitt Bkjerne-antistoffer (Monolisa anti-HBc Plus, Bio-Rad), hepatitt B-overflateantigen (Monolisa HBs Ag Plus, Bio-Rad) og hivantistoffer (Genscreen HIV-1/2 versjon 2, Bio-Rad).

\section{STATISTISKE ANALYSER}

To analyseserier ble foretatt ved hjelp av SPSS versjon 11.o. I begge analyser var anti-HCVstatus avhengig variabel og mulige risikofaktorer for hepatitt C-smitte var uavhengige variabler. I første analyseserie ble univariatanalyser gjennomført ved sammenlikninger mellom grupper. Pearsons khikvadrattest eller t-test ble brukt avhengig av data. En tosidig p-verdi < o,o5 ble vurdert å være statistisk signifikant. Deretter ble risikofaktorer som var statistisk signifikant assosiert med seropositivitet inkludert i en multivariat logistisk regresjonsmodell. Modellen kontrollerte for sosiodemografiske variabler og ga justerte oddsratioer (OR) med $95 \%$ konfidensintervaller. Nagelkerkes R-kvadrattest ble brukt for å angi den forklarte variasjonen i modellen. Variasjonen $\left(\mathrm{R}^{2}\right)$ er omskrevet som en prosentsats. 
Studieprotokollen var i samsvar med Helsinki-deklarasjonen av 1975 og ble anbefalt av den regionale etiske komité i Oslo og Datatilsynet. All deltakelse i studien var frivillig og et skriftlig informert samtykke ble undertegnet av alle som deltok. Resultatet av hepatitt Cundersøkelsene ble tilsendt deltakerne med en fortolkning av resultatet. Deltakere som var kronisk infisert ble tilbudt medisinsk oppfølging.

\section{Resultater}

Serologiske undersøkelser ble foretatt av 410 brukere, og 327 av disse valgte å delta i intervjuundersøkelsen. Gjennomsnittsalderen blant de 327 respondentene var 34 år (spredning 18-56), og av disse var 209 (64\%) menn. Gjennomsnittlig debutalder for intravenøst stoffmisbruk var 20 år (spredning 10-41), og gjennomsnittlig varighet av misbruket var 14 år (spredning o-39). I løpet av de siste fire ukene før undersøkelsen hadde 305 (93\%) injisert minst én gang. Det foretrukne rusmidlet var opiater hos 268 (82 \%) (tab 1), og blant disse oppga $195(73 \%)$ at de injiserte daglig. Til sammenlikning oppga $28(49 \%)$ av dem som hovedsaklig brukte amfetamin at de injiserte daglig $(\mathrm{p}<0,001)$.

\section{Tabell 1}

Karakteristika og risikoatferd etter anti-hepatitt C (anti HCV)-status hos 327 injiserende stoffmisbrukere i Oslo. Univariabel og korrigert oddsratio for anti-HCV-positivitet ${ }^{1}$

\begin{tabular}{|c|c|c|c|c|c|c|}
\hline \multirow[b]{2}{*}{ Karakteristika (\%) } & \multirow{2}{*}{$\begin{array}{c}\text { Alle } \\
\mathbf{n}=\mathbf{3 2 7}\end{array}$} & \multirow{2}{*}{$\begin{array}{c}\begin{array}{c}\text { Anti-HCV- } \\
\text { positive }\end{array} \\
\mathbf{n}=\mathbf{2 6 5} \\
\end{array}$} & \multicolumn{2}{|c|}{ Univariabel modell } & \multicolumn{2}{|c|}{$\begin{array}{c}\text { Korrigert } \\
\text { multivariabel modell }\end{array}$} \\
\hline & & & $\begin{array}{l}\text { Oddsratio } \\
(95 \% \mathrm{KI})\end{array}$ & P-verdi & $\begin{array}{l}\text { Oddsratio } \\
(95 \% \mathrm{KI})\end{array}$ & P-verdi \\
\hline Kjønn (\%) & & & & 0,913 & & \\
\hline Kvinner & 118 & $96(81)$ & $1,0(0,7-1,6)$ & & & \\
\hline Menn & 209 & $169(81)$ & & & & \\
\hline Alder & & & & $\begin{array}{c}<, 001 \\
0,\end{array}$ & & 0,004 \\
\hline$\leq 34 \mathrm{arr}$ & 166 & $120(72)$ & & & & \\
\hline$>34$ år & 161 & $145(90)$ & $3,5(1,8-6,9)$ & & $3,3(1,5-7,7)$ & \\
\hline Uten fast bolig (\%) & & & & 0,530 & & - \\
\hline $\mathrm{Ja}$ & 45 & $38(84)$ & $1,2(0,8-2,1)$ & & & \\
\hline $\mathrm{Nei}$ & 282 & $227(80)$ & & & & \\
\hline Alkoholkonsum (\%) & & & & 0,798 & & - \\
\hline$<30 \mathrm{~g}$ alkohol/dag & 293 & $238(81)$ & $1,1(0,6-1,9)$ & & & \\
\hline$\geq 30 \mathrm{~g}$ alkohol/dag & 34 & $27(79)$ & & & & \\
\hline $\begin{array}{l}\text { Debutalder intravenøst } \\
\text { misbruk (\%) }\end{array}$ & & & & $\begin{array}{c}< \\
0,001\end{array}$ & & \\
\hline$<20$ år & 188 & $172(92)$ & $5,4(2,8-9,9)$ & & $3,7(1,8-7,9)$ & 0,001 \\
\hline > 20 år & 138 & $92(67)$ & & & & \\
\hline $\begin{array}{l}\text { Varighet av intravenøst } \\
\text { misbruk (\%) }\end{array}$ & & & & $\begin{array}{c}< \\
0,001\end{array}$ & & 0,017 \\
\hline
\end{tabular}




\begin{tabular}{|c|c|c|c|c|c|c|}
\hline \multirow[b]{2}{*}{ Karakteristika (\%) } & \multirow{2}{*}{$\begin{array}{c}\text { Alle } \\
\mathrm{n}=\mathbf{3 2 7}\end{array}$} & \multirow{2}{*}{$\begin{array}{c}\begin{array}{c}\text { Anti-HCV- } \\
\text { positive }\end{array} \\
n=265\end{array}$} & \multicolumn{2}{|c|}{ Univariabel modell } & \multicolumn{2}{|c|}{$\begin{array}{c}\text { Korrigert } \\
\text { multivariabel modell }\end{array}$} \\
\hline & & & $\begin{array}{l}\text { Oddsratio } \\
(95 \% \mathrm{KI})\end{array}$ & P-verdi & $\begin{array}{l}\text { Oddsratio } \\
(95 \% \mathrm{KI})\end{array}$ & P-verdi \\
\hline$<5$ år & 53 & $25(47)$ & & & & \\
\hline$>5$ år & 274 & $240(88)$ & $\begin{array}{c}7,9(3,9- \\
15,9)\end{array}$ & & $2,8(1,2-6,3)$ & \\
\hline Foretrukne rusmidler (\%) & & & & $\begin{array}{c}< \\
0,001\end{array}$ & & 0,020 \\
\hline Opiater & 268 & $225(84)$ & $2,6(1,3-5,2)$ & & $2,8(1,2-6,4)$ & \\
\hline Amfetamin & 57 & $38(67)$ & & & & \\
\hline $\begin{array}{l}\text { Hyppighet av injeksjoner } \\
\text { (\%) }\end{array}$ & & & & 0,01 & & 0,135 \\
\hline Daglig & 225 & $191(85)$ & $2,1(1,2-3,9)$ & & $1,8(0,8-3,7)$ & \\
\hline Sjeldnere enn daglig & 102 & $74(73)$ & & & & \\
\hline $\begin{array}{l}\text { Noen gang delt sprøyte? } \\
\text { (\%) }\end{array}$ & & & & $\begin{array}{c}< \\
0,001\end{array}$ & & 0,014 \\
\hline Ja & 250 & $217(87)$ & $4,0(2,1-7,4)$ & & $2,5(1,2-5,2)$ & \\
\hline Nei & 77 & $48(62)$ & & & & \\
\hline $\begin{array}{l}\text { Delt sprøyte siste fire } \\
\text { uker? (\%) }\end{array}$ & & & & 0,173 & & - \\
\hline Ja & 50 & $44(88)$ & $1,8(0,7-5,6)$ & & & \\
\hline Nei & 223 & $221(80)$ & & & & \\
\hline $\begin{array}{l}\text { Fått eller gitt hjelp med } \\
\text { å injisere? (\%) }\end{array}$ & & & & 0,034 & & 0,833 \\
\hline Ja & 275 & $229(83)$ & $2,2(1,1-4,5)$ & & $0,9(0,3-2,3)$ & \\
\hline Nei & 52 & $36(69)$ & & & & \\
\hline $\begin{array}{l}\text { Noen gang delt dotter? } \\
(\%)\end{array}$ & & & & 0,841 & & \\
\hline Ja & 225 & $183(81)$ & $1,1(0,6-1,9)$ & & & \\
\hline Nei & 102 & $82(80)$ & & & & \\
\hline $\begin{array}{l}\text { Noen gang delt } \\
\text { kokeskje? (\%) }\end{array}$ & & & & 0,274 & & \\
\hline Ja & 283 & $232(82)$ & $1,5(0,7-3,1)$ & & & \\
\hline Nei & 44 & $33(75)$ & & & & \\
\hline $\begin{array}{l}\text { Noen gang delt } \\
\text { skyllevann? (\%) }\end{array}$ & & & & 0,541 & & \\
\hline Ja & 239 & $196(82)$ & $1,3(0,7-2,3)$ & & & \\
\hline Nei & 88 & $69(78)$ & & & & \\
\hline Noen gang fengslet? (\%) & & & & $\begin{array}{c}< \\
0,001\end{array}$ & & 0,183 \\
\hline
\end{tabular}




\begin{tabular}{|c|c|c|c|c|c|c|}
\hline \multirow[b]{2}{*}{ Karakteristika (\%) } & \multirow{2}{*}{$\begin{array}{c}\text { Alle } \\
\mathbf{n}=\mathbf{3 2 7}\end{array}$} & \multirow{2}{*}{$\begin{array}{c}\begin{array}{c}\text { Anti-HCV- } \\
\text { positive }\end{array} \\
\text { n=265 }\end{array}$} & \multicolumn{2}{|c|}{ Univariabel modell } & \multicolumn{2}{|c|}{$\begin{array}{c}\text { Korrigert } \\
\text { multivariabel modell }\end{array}$} \\
\hline & & & $\begin{array}{l}\text { Oddsratio } \\
(95 \% \mathrm{KI})\end{array}$ & P-verdi & $\begin{array}{c}\text { Oddsratio } \\
(95 \% \mathrm{KI})\end{array}$ & P-verdi \\
\hline Ja & 255 & $220(86)$ & $4,0(2,1-7,7)$ & & $1,7(0,8-3,8)$ & \\
\hline Nei & 69 & $42(61)$ & & & & \\
\hline Injisert i fengsel? (\%) & & & & $\begin{array}{c}< \\
0,001\end{array}$ & & 0,045 \\
\hline Ja & 113 & $106(94)$ & $\begin{array}{c}5,3(2,3- \\
14,3)\end{array}$ & & $2,7(1,1-7,1)$ & \\
\hline $\mathrm{Nei}$ & 212 & $157(74)$ & & & & \\
\hline Backloading²? (\%) & & & & $\begin{array}{c}< \\
0,001\end{array}$ & & 0,042 \\
\hline Ja & 251 & $214(85)$ & $2,8(1,5-5,3)$ & & $2,2(1,1-4,9)$ & \\
\hline Nei & 76 & $51(67)$ & & & & \\
\hline $\begin{array}{l}\text { Tatovering, } \\
\text { uprofesjonell (\%) }\end{array}$ & & & & 0,011 & & 0,147 \\
\hline Ja & 64 & $59(92)$ & $\begin{array}{c}3,3(1,2- \\
10,9)\end{array}$ & & $2,3(0,8-6,9)$ & \\
\hline Nei & 263 & $206(78)$ & & & & \\
\hline [i] & & & & & & \\
\hline
\end{tabular}

[i] ${ }^{1}$ Multivariatanalysen er basert på 322 respondenter og inkluderte alle faktorer som var signifikant assosiert med anti-HCV-positivitet i univariatanalysen

${ }^{2}$ En praksis hvor en dose trekkes opp i en felles sprøyte, stempelet trekkes ut og flere brukere kan trekke opp en dose i egen sprøyte

\section{SEROLOGISKE UNDERSØKELSER}

Anti-HCV ble påvist hos 265 (81\%) og HCV-RNA hos 165 (51 \%) av de 327 deltakerne. HCV-RNA ble påvist i serum hos 165 av 265 (62 \%) anti-HCV-positive personer. Blant anti-HCV-positive kvinner var 51/96 (53\%) positive for HCV-RNA sammenliknet med 114/169 (67\%) seropositive menn ( $\mathrm{p}=0,02)$. Fire personer (1\%) var hivpositive og ti (3\%) var HBsAg-positive.

HCV-RNA/anti-HCV-ratioen falt med økende varighet av stoffmisbruket. HCV-RNA ble påvist hos 20/25 (80 \%) anti-HCV-positive personer som hadde injisert mindre enn fem år og hos $145 / 240$ (6o \%) av dem som hadde injisert fem år eller mer $(p=0,06)$.

\section{RISIKOFAKTORER FOR SMITTE}

I univariatanalysen fant vi at positiv anti-HCV-test var assosiert med følgende variabler: alder > 34 år (gjennomsnittsalder i materialet), varighet av misbruk > fem år, debutalder $<20$ år, daglig injisering, deling av sprøyter, heroin i motsetning til amfetamin som foretrukne rusmiddel, å ha hjulpet eller mottatt hjelp til å injisere, å ha vært fengslet, å ha delt dose via felles sprøytekammer og å ha ikke-profesjonelt utført tatovering. Deling av annet brukerutstyr enn sprøyter var ikke assosiert med hepatitt C-smitte (tab 1).

I en multippel logistisk regresjonsmodell var påvisning av anti-HCV assosiert med alder > 34 år, debutalder for intravenøst misbruk $<20$ år, varighet av misbruk $>$ fem år, deling av sprøyter, deling av dose fra felles sprøyte, injisering i fengsel og å ha heroin som foretrukne rusmiddel (tab 1). Den forklarte variasjonen var o,449 (Nagelkerkes R-kvadrattest). 
Blant respondentene oppga 250 av 327 ( $76 \%$ ) at de hadde delt sprøyter ved minst én anledning. Sprøytedeling blant dem som hadde begynt å injisere før sprøytebussen kom i drift i 1988, hadde forekommet hos 119/145 (82,1\%) sammenliknet med hos 131/181 (72,4\%) blant dem som begynte etter $1988(p=0,03)$.

Av dem som hadde injisert de siste fire ukene før intervjuet, oppga 50/305(16\%) at de hadde delt sprøyter i denne perioden. I en post hoc-analyse fant vi at sprøytedeling siste fire uker hadde foregått hos 14/39 (36\%) gifte eller samboende og blant 36/266 (14\%) aleneboende. Det var ingen vesentlig forskjell i frekvensen av sprøytedeling verken hos kvinner sammenliknet med menn ( $20 \%$ og $14 \%$ ), hos dem som hadde injisert mindre eller mer enn fem år (16\% og 20 \%), hos dem som var yngre eller eldre enn 34 år (16\% i begge grupper) eller hos dem som brukte heroin sammenliknet med dem som brukte amfetamin (17\% og $16 \%)$.

\section{FENGSLING}

De aller fleste (255/327; $78 \%$ ) hadde vært fengslet ved minst én anledning (tab 1). Under soning hadde 113/255 (44\%) injisert og 6o/113 (53\%) hadde delt sprøyter. Hepatitt C-smitte var vanligere blant dem som hadde injisert i fengsel enn blant fengslede som ikke hadde injisert ( $94 \%$ versus $74 \%$ ).

\section{Diskusjon}

Blant annet deling av sprøyter, særlig i fengsel, var assosiert med høy risiko for hepatitt Csmitte i vår studie. Vi kunne derimot ikke påvise noen sammenheng mellom deling av annet injiseringsutstyr enn sprøyter og hepatitt C-smitte, men deling av dose med andre fra felles sprøytepumpe ser ut til å være en smittevei. Sprøytedebut i ung alder og lang varighet av misbruket var assosiert med $ø$ kt sannsynlighet for smitte. Assosiasjonen med langvarig misbruk gjenspeiler antakeligvis en akkumulert risiko for eksponering. Siden dette er en tverrsnittsundersøkelse, kan vi imidlertid ikke utelukke at det representerer en kohorteffekt. Den høye prevalensen hos dem som har injisert lengst, kan være uttrykk for en høyere insidens i en tidligere periode, f.eks. før utdeling av rene sprøyter ble iverksatt i 1988.

Deltakere som oppga heroin som foretrukne rusmiddel hadde høyere prevalens enn de som først og fremst bruker amfetamin. Dette gjaldt uavhengig av andre faktorer assosiert med hepatitt C-smitte og kan reflektere at type misbruk knytter de rusavhengige til forskjellige nettverk med forskjellig prevalens av hepatitt C-virus. Forskjellen kan også skyldes at amfetaminbrukere injiserer sjeldnere enn heroinbrukere.

Sprøytedeling er en velkjent smittevei for hepatitt C-virus, og det er beregnet at to av tre smittetilfeller ville unngås hvis all sprøytedeling opphørte (tilskrivbar risiko 6o \%) $(\underline{2}, \underline{8}, 9$. $)$. Tross god tilgjengelighet av rene sprøyter i Oslo gjennom sprøytebussen er deling fortsatt vanlig, og en av sju oppga at de hadde delt sprøyter siste måned. Dette er kanskje skuffende, men i samsvar med erfaringer fra andre områder med god tilgang på rene sprøyter $(9, \underline{10})$. Mindre forventet var det at en av fire med anti-HCV i vår studie oppga at de aldri hadde delt sprøyter. Vi må derfor mistenke at andre smitteveier enn sprøytedeling kan ha betydning. Ved laboratorieundersøkelser har man kunnet påvise HCV-RNA i $25-40 \%$ av bomullsdotter brukt som filter, i skyllevann og på kokeskjeer (11). Epidemiologiske undersøkelser har et stykke på vei bekreftet at slikt brukerutstyr kan overføre hepatitt C-smitte, men studiene er

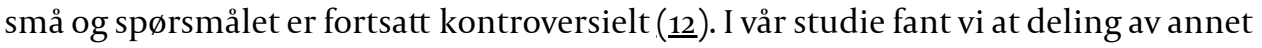
brukerutstyr enn sprøyter var vanlig, men at slik praksis ikke var assosiert med hepatitt Csmitte. Hva så med seksuell smitte? Vårt spørreskjema omhandlet ikke seksualatferd og vi kan derfor ikke belyse dette spørsmålet, men andre har vist at seksuell overføring av viruset er svært sjelden, også blant sprøytemisbrukere $(13,14)$. 
Deling av sprøyter var vanlig blant brukere av sprøytebussen i Oslo. Hvordan kan dette skje når rene sprøyter er lett tilgjengelig og gratis? Sprøytedeling var vanligere blant dem som var gift eller hadde samboere enn blant dem som bodde alene, noe som er forenlig med at en betydelig andel av sprøytedelingen skjer mellom seksualpartnere. Videre fant vi at sprøytedeling ofte forekommer i fengsel. En slik assosiasjon har man også funnet i en australsk undersøkelse (15). Alt i alt må vi allikevel si at vi vet lite om hvorfor sprøytedeling fortsatt skjer.

Kun $1 \%$ av respondentene i denne studien var hivsmittet, mens $80 \%$ hadde vært eksponert for hepatitt C-virus. Hvordan kan vi forklare denne tilsynelatende diskrepansen? For det

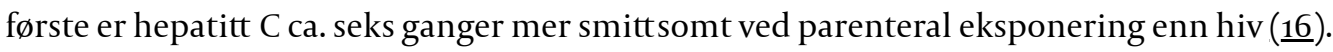
Videre vil det være langt mer sannsynlig at en episode med sprøytedeling i Oslo innebærer eksponering for hepatitt $\mathrm{C}$ enn for hiv. Med andre ord: insidensen er avhengig av prevalensen. Et annet viktig fenomen som begrenser hivepidemien blant misbrukere, er at hivsmittede sjeldnere deler sprøyter enn andre misbrukere (17.).

Det er flere svakheter ved denne studien. Dette er en tverrsnittsundersøkelse og den kan derfor kun si noe om assosiasjoner og ingenting med stor sikkerhet om kausalitet. I hvilken grad misbrukerne vi intervjuet er representative for hele misbrukerpopulasjonen i Oslo, er dessuten usikkert. Vi vet ikke hvor mange som benyttet sprøyteutdelingsprogrammet i perioden vi foretok undersøkelsen. Vi kan derfor ikke si nøyaktig hvor stor andel av mulige deltakere som ble intervjuet, og vi kan si lite om hvorvidt det foreligger en seleksjonsskjevhet i utvalget. I Statens institutt for alkoholforsknings rapport fra 2006 anslår man at gjennomsnittsalderen blant sprøytemisbrukere i Norge er 36 år og at 2/3 er menn (묘), noe som svarer godt til sammensetningen av vårt materiale. Vi har i denne undersøkelsen samlet informasjon om risikoatferd som går svært langt tilbake i tid, slik at hukommelsesskjevhet også kan være et problem. Mange av respondentene var dessuten klar over sin hepatitt C-status (19), noe som kan påvirke hvilken risikoatferd de har husket. Forskjellige former for konfundering må også tas i betraktning. Ikke minst kan det være vanskelig å avsløre en assosiasjon mellom hepatitt C-smitte og deling av annet utstyr enn sprøyter, siden dette antakelig er risikoatferd som ofte skjer samtidig.

Studien gir allikevel ny og viktig informasjon som vi mener bør få konsekvenser. Hepatitt C er en alvorlig sykdom som forblir hyperendemisk blant stoffmisbrukere i Oslo. Vi tror kontinuerlig informasjon om hepatitt C i miljøet er viktig og at man særlig bør være oppmerksom på problemet med sprøytedeling for par. Videre bør fokus rettes mot hvordan man kan unngå smitte i fengsel. Etter vårt syn bør man vurdere utdeling av rene sprøyter i fengsel. I tillegg er det etter vår erfaring et stort behov for individuell og gatenær diagnostikk av blodbårne virusinfeksjoner i denne gruppen (19).) Slik diagnostikk bør følges av god informasjon, og ressurser må settes inn for å igangsette behandling av hepatitt C, særlig til dem som allerede er i ferd med å utvikle cirrhose.

\section{Konklusjon}

Hepatitt C-smitte blant sprøytemisbrukere i Oslo var blant annet assosiert med deling av dose fra felles sprøyte og deling av sprøyter, særlig i fengsel. Deling av annet utstyr enn sprøyter var ikke assosiert med hepatitt C-smitte. De som har startet med sprøyter i ung alder og de som først og fremst bruker heroin, har særlig stor sannsynlighet for å være smittet.

Vi takker for bidrag fra Liv Heidi Bjerkmo, Anlaug Lia, Arne S. Andresen og Kirsten Holde. Studien ble gjennomført med støtte fra Rusmiddeletaten og davcerende Helsevernetaten i Oslo kommune. 


\section{Oppgitte interessekonflikter:}

Olav Dalgard har mottatt honorar for foredrag og forskningsstøtte fra Roche Norge og Schering-Plough. De øvrige forfatterne har ingen oppgitte interessekonflikter.

\section{LITTERATUR}

1. World Health Organization. Hepatitis C: global prevalence. Wkly Epidemiol Rec 1999; 74: 425-7.

2. Hagan H. Syringe exchange and risk of infection with hepatitis B and C viruses. Am J Epidemiol 1999; 149: 203-13.

3. Kielland KB, Siebke JC. Hepatitt A-, B- og C-markører hos norske stoffmisbrukere i perioden 197589. Tidsskr Nor Lægeforen 1991; 111: 821-4.

4. Dalgard O, Jeansson S, Skaug K et al. Hepatitis C in the general adult population of Oslo: prevalence and clinical spectrum. Scand J Gastroenterol 2003; 38: 864-70.

5. Seeff LB. Natural history of hepatitis C. Hepatology 1997; 26 ( $\operatorname{suppl} 1$ ): 21-8.

6. Blystad H, Svendsen PK. Hepatitt C 10 år etter. MSIS-rapport nr. 1/20oo. Oslo: Nasjonalt folkehelseinstitutt, 2000.

7. Blystad H, Nilsen $\emptyset$. Stoffmisbrukere og infeksjoner. MSIS-rapport nr. 48/20oo. Oslo: Nasjonalt folkehelseinstitutt, 2000.

8. Crofts N, Jolley D, Kaldor J et al. Epidemiology of hepatitis C virus infection among injecting drug users in Australia. J Epidemiol Community Health 1997; 51: 692-7.

9. Hagan $\mathrm{H}$, Thiede $\mathrm{H}$, Weiss NS et al. Sharing of drug preparation equipment as a risk factor for hepatitis C. Am J Public Health 2001; 91: 42-6.

10. Garfein RS, Vlahov D, Galai N et al. Viral infections in short-term injection drug users: the prevalence of the hepatitis $C$, hepatitis B, human immunodeficiency, and human T-lymphotropic viruses. Am J Public Health 1996; 86: 655-61.

11. Crofts N, Caruana S, Bowden S et al. Minimising harm from hepatitis C virus needs better strategies. BMJ 2000; 321: 899.

12. De P, Roy E, Boivin JF et al. Risk of hepatitis $C$ virus transmission through drug preparation equipment: a systematic and methodological review. J Viral Hepat 2008; 15: 279-92.

13. Vandelli C, Renzo F, Romano L et al. Lack of evidence of sexual transmission of hepatitis $C$ among monogamous couples: results of a 10-year prospective follow-up study. Am J Gastroenterol 2004; 99: $855^{-9}$.

14. McMahon JM, Pouget ER, Tortu S. Individual and couple-level risk factors for hepatitis C infection among heterosexual drug users: a multilevel dyadic analysis. J Infect Dis 2007; 195: 1572-81.

15. Crofts N, Stewart T, Hearne P et al. Spread of bloodborne viruses among Australian prison entrants. BMJ 1995; 310: $285-8$.

16. Moloughney BW. Transmission and postexposure management of bloodborne virus infections in the health care setting: where are we now? CMAJ 2001; 165:445-51.

17. Miller M, Mella I, Moi $\mathrm{H}$ et al. HIV and hepatitis $\mathrm{C}$ virus risk in new and longer-term injecting drug users in Oslo, Norway. J Acquir Immune Defic Syndr 2003; 33:373-9.

18. Bretteville-Jensen AL, Amundsen EJ. Omfang av sprøytemisbruk i Norge. Rapport nr. 5/20o6. Oslo: Statens institutt for rusmiddelforskning, 2006.

19. Dalgard O, Egeland A, Skaug K et al. Health-related quality of life in active injecting drug users with and without chronic hepatitis C virus infection. Hepatology 2004; 39: 74-80.

Publisert: 15. januar 2009. Tidsskr Nor Legeforen. DOI: 10.4045/tidsskr.09.35002

Manuskriptet ble mottatt 7.5. 2008 og godkjent 30.10. 2008. Medisinsk redaktør Åslaug Helland.

(C) Tidsskrift for Den norske legeforening 2023. Lastet ned fra tidsskriftet.no 26. april 2023. 